\title{
Mass movement-induced tsunamis: main effects during the Patagonian Fjordland seismic crisis in Aisén (45'25'S), Chile
}

\author{
José Antonio Naranjo ${ }^{1}$, Manuel Arenas ${ }^{1}$, Jorge Clavero², Oscar Muñoz ${ }^{3}$ \\ ${ }^{1}$ Servicio Nacional de Geología y Minería, Avda. Santa María 0104, Providencia, Santiago, Chile. \\ jnaranjo@sernageomin.cl; marenas@sernageomin.cl \\ 2 Antofagasta Minerals, Dario Urzúa 2165, Santiago, Chile. \\ jclavero@aminerals.cl \\ ${ }^{3}$ Oficina de Ordenamiento Territorial, Municipalidad de Puerto Aisén, Puerto Aisén, Chile. \\ delta185@gmail.com
}

\begin{abstract}
The epicentre of the long-lasting seismic crisis started on the evening of January 22, 2007 and it was located $20 \mathrm{~km}$ to the west of Puerto Chacabuco in the Patagonian fjordland, Chile ( $\left.45^{\circ} 25^{\prime} \mathrm{S}\right)$. Approximately 7,000 events were recorded up to early May, four of which reached magnitudes greater than 5 (Richter), with local intensities up to VII in Puerto Chacabuco and Puerto Aisén and VI in Coihaique. The seismic swarm was located within the Liquiñe-Ofqui Fault Zone (LOFZ), which controls the emplacement of several monogenetic volcanic cones and larger stratovolcanoes. The January 23 (Ms 5,2) and April 1 (Ms 5,4) events caused minor damages in salmon industry installations near the epicentral zone, however the earthquake that occurred at 13:54 hours (local time) on April 21 (Mw 6,2) triggered various mass movements on the Fiordo Aisén slopes and generated tsunamis. Debris flows and tsunami waves caused the death of three people and the disappearance of seven, in addition to severe damages to the salmon industry installations. A similar phenomenon had occurred in 1927, but then fewer people inhabited the area. Initially, confusion dominated the scientific coordination of the emergency management due to seismic data misinterpretation.
\end{abstract}

Keywords: Tsunami, Mass movements, Seismic crisis, Land use planning, Patagonian fjordland, Fiordo Aisén.

RESUMEN. Tsunamis inducidos por movimientos en masa: principales efectos durante la crisis sísmica de la Patagonia Archipelágica en Aisén (45'25'S), Chile. En la noche del 22 de enero de 2007 comenzó una crisis sísmica, cuyos epicentros se localizaron principalmente en el fiordo Aisén, a unos $20 \mathrm{~km}$ al noroeste de Puerto Chacabuco, en la zona archipelágica de Patagonia, en Chile ( $45^{\circ} 25^{\prime}$ 'S). Hasta comienzos de mayo, los sismógrafos habían registrado cerca de 7.000 sismos, de los cuales cuatro habían sobrepasado la magnitud 5 (Richter), con intensidades locales de hasta VII en Puerto Chacabuco y Puerto Aisén y VI en Coihaique. El enjambre sísmico está asociado a estructuras geológicas de la Zona de Falla Liquiñe-Ofqui (ZFLO) la cual, además, controla el emplazamiento de numerosos conos volcánicos, así como estratovolcanes mayores. Aunque los sismos del 23 de enero (Ms 5,2) y 1 de abril (Ms 5,4) de 2007 produjeron algunos daños menores en instalaciones de salmoneras cercanas a la zona epicentral, el sismo ocurrido a las 13:54 hora local del 21 de abril (Mw 6,2) fue el que produjo los mayores efectos, generándose diversos tipos de remociones en masa en laderas de las riberas del fiordo Aisén, tres de las cuales, con los mayores volúmenes, generaron veloces tsunamis. Flujos de detritos y tsunamis causaron la muerte de tres personas y la desaparición de siete, y severos daños en las instalaciones de las salmoneras. En una primera instancia, las características del proceso probablemente similar a uno ocurrido en 1927, cuando en la zona había escasa población, fueron novedosas y produjeron confusión y errores en la coordinación del manejo de la emergencia. 


\section{Introduction}

At the end of January 2007, a significant seismic crisis (seismic swarm) affecting the Patagonian fjordland region in the Aisén County $\left(45^{\circ} 25^{\prime} \mathrm{S}\right.$, Fig. 1) began. Until the middle of June 2007, the average number of events showed an oscillatory, but descending tendency (Informe Actividad Sísmica Puerto Aisén, http://ssn.dgf.uchile.cl; Barrientos et al., 2007). Events larger than magnitude 5 occurred in January 23, February 24 and April 1 and 21, the latter being the largest (Mw 6,2, http://earthquake. usgs.gov/regional/neic/). Minor mass movements were produced during the events of January 23 (Ms 5,2) and April 1 (Ms 5,4) which triggered a small tsunami and caused some minor damages to the salmon farms near the epicentral zone (Sepúlveda and Serey, 2009, this volume). The major direct and secondary effects were produced during the April 21 earthquake and consisted of different types of mass movements on the steep slopes of the Fiordo Aisén coasts near Isla Mentirosa (Fig. 1). Three of the more voluminous mass movements triggered destructive tsunamis.

The use of the accepted crisis protocols (e.g., IAVCEI, Subcommitee for Crisis Protocols, 1999) at an earlier stage would have helped to reduce the initial communication problems within the multidisciplinary emergency management team. In this geologic note, we present the main catastrophic effects of the seismic crisis which had disastrous consequences with three fatalities and seven missing people, in addition to important losses for the salmon farm industry in the area. This study also allowed a preliminary evaluation of the frequent geological hazards that threaten the fjordland zone in Patagonia, particularly those associated to local seismic activity.

\section{Geological Setting}

The main geological features of the studied region are the Meso-Cenozoic north-south oriented Patagonian Batholith (Servicio Nacional de Geología y

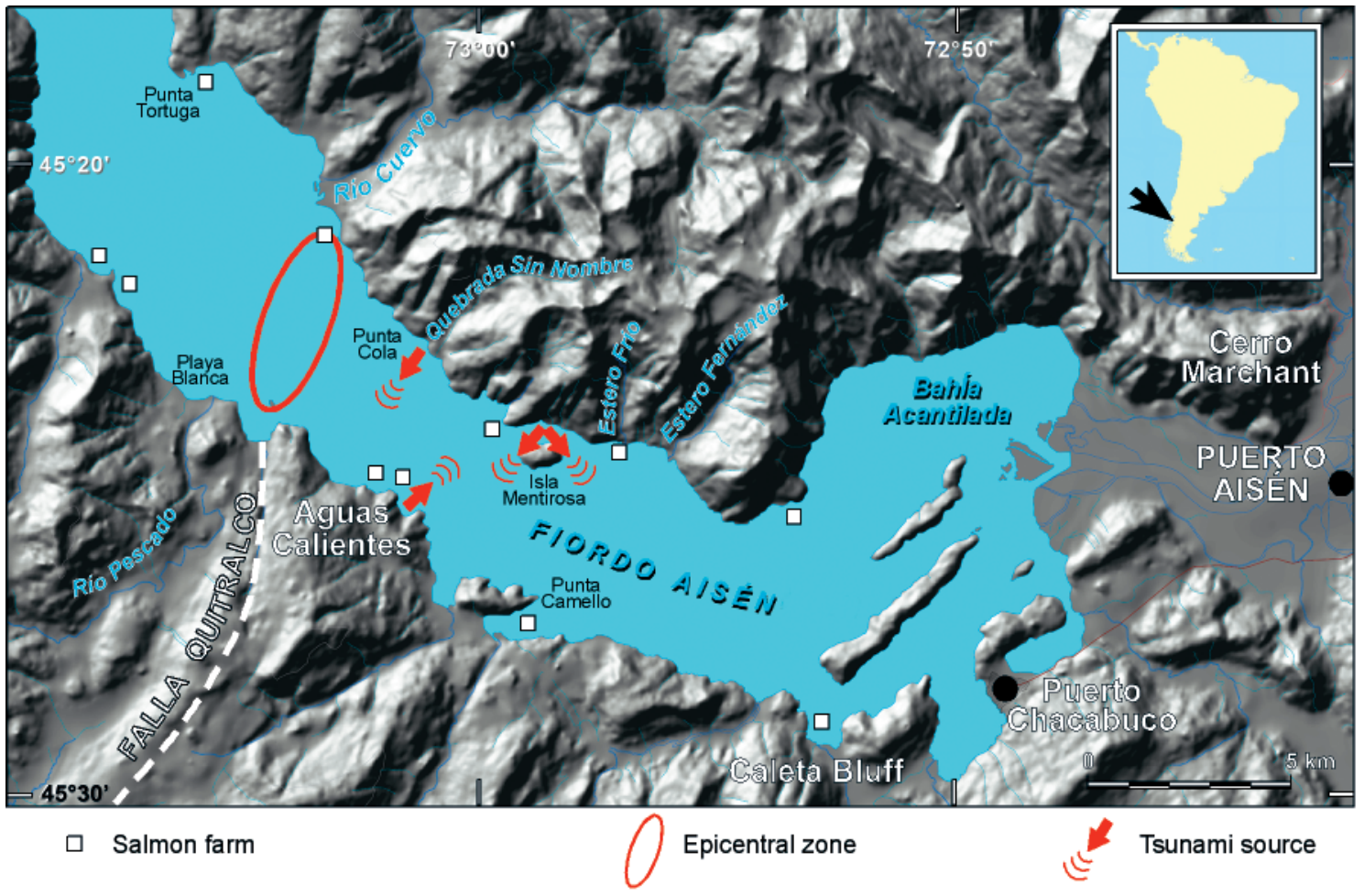

FIG. 1. MDE map illustrating the Fiordo Aisén to the west of Puerto Chacabuco. The epicentral zone, salmon farms and the April 21, 2007 tsunami sources are noted. 
Minería, 2002) and an important longitudinal active fault system known as the Liquiñe-Ofqui Fault Zone (LOFZ) (Hervé, 1976, 1984; Hervé et al., 1979; Cembrano et al., 1996). One of the related fault branches of the LOFZ along Quitralco valley (SWNE), hosted the 2007 seismic swarm, just across the Fiordo Aisén (Fig. 1). Glacial erosion following fault zones have modelled much of the morphology of the Patagonian archipelago, forming steep slopes on exhumed rocks and structures. The main volcanoes of the area, such as Macá, Cay and a number of monogenetic pyroclastic cones and parasitic cones (D'Orazio et al., 2003), in addition to Hudson caldera (Naranjo et al., 1993; Orihashi et al., 2004; Gutiérrez et al., 2005), have been built along the faults associated to the LOFZ since thousands of years ago (Servicio Nacional de Geología y Minería, 2002; Cembrano et al., 2008; Lange et al., 2008).

The main geological hazards of the Patagonian fjordland are related to mass movements induced by heavy rainfall and volcanic activity (Naranjo, 1991; Naranjo et al., 1993; Naranjo and Stern, 2004). However, since the fjordland of Patagonia was colonised just from the beginning of the $20^{\text {th }}$ century, the historical record of earthquakes is limited to the events that occurred on November 21, 1927 (Greve, 1964 ) and on March 3, 2002, with an epicentre located west of Puerto Aisén $(\mathrm{Mw}=5,3$; depth $=33$ $\mathrm{km})$ and another one north of Laguna San Rafael $(\mathrm{Mw}=5,2 ;$ depth $=33 \mathrm{~km})$. Temporary monitoring arrays have shown shallow seismic foci along the LOFZ that amplify the seismic hazards in the region noticeable (Lange et al., 2008).

\section{A brief chronicle of a historical seismic event}

The city of Puerto Aisén was founded as a small fishing and timber port during the late 1920's. Tales from older people of this area shed light on a disaster that occurred at that time. Interviews obtained during this study indicate that the whole northern part of the Patagonian fjordland, from Chiloé to Aisén, was severely affected -for at least two months- by a seismic crisis. In fact, a very reliable testimony (Mr. Gustavo Bahamondes Igor, after his father Mr. Saturnino Bahamondes) indicates that a particularly intense earthquake occurred in November 1927, which also generated important landslides and tsunamis in the fjords (http://www.tecpetrol.com/patagoni$\cos /$ cuaderno15/default.htm). All these reports were complemented by Greve (1964) who located the epicentre around Canal Moraleda $\left(44,5^{\circ} \mathrm{S}\right.$ y $\left.73^{\circ} \mathrm{W}\right)$ and estimated the magnitude for the earthquake of November 21, 1927 in 7.1, 'which produced large landslides, earthflows and tsunamis, and many tree trunks were floating on the channels'.

Based on these accounts, March 28 and April 20, 2007, Sernageomin distributed explicit reports suggesting the evacuation of the most vulnerable fjordland shoreline places.

\section{Main effects of the April 21, 2007 earthquake}

A few seconds before 13:54 hours (local time=UTC-4), on April 21, the largest seimic episode in magnitude and intensity, took place, with an epicentre located around the zone previously defined by earlier (January-April) activity (Naranjo et al., 2007b; www.sernageomin.cl; www.sismologia.cl), at a depth of less than $9 \mathrm{~km}$ (S. Barrientos, oral communication 2007). Since the seismic array installed for the monitoring was almost completely lost due to the tsunami, it was impossible to determine the focus depth precisely. Even so, the intensities recorded around the epicentral zone (VIII a IX) supported a shallow location for the earthquake focus. Intensities decreased to VII at Puerto Aisén and Puerto Chacabuco; VI at Coihaique; V at Balmaceda and IV at Cochrane (http://ssn.dgf. uchile.cl). As a consequence, the Fiordo Aisén and inland area adjacent to Puerto Aisén were the most affected ones.

Different kind of mass movements occurred. Three of the most voluminous ones caused tsunamis which repeatedly overran the shallowest coastal areas of the fjord. As a consequence, debris flows and tsunamis caused the death of three people and the disappearance of seven, in addition to severe damages to the the salmon industry installations.

Reports by the United States Geological Survey (http://earthquake.usgs.gov/regional/neic/), indicated that the seismic focal mechanism was a dextral strike slip movement along one of the LOFZ branches which had a northward horizontal displacement on the west block (J. Cembrano, oral communication, 2007).

\footnotetext{
Greve, F. 1964. Historia de la Sismología en Chile, Instituto de Geofísica y Sismología, Universidad de Chile: 138 p. (unpublished).
} 


\section{Mass Movements}

Steep slopes along glaciated valleys, a dense vegetation cover developed on a thin layer of soil (less than one meter) and jointing of granitic rocks are the main controlling factors of different landslide types in this region, which are frequently triggered by rainfall. On April 21, 2007 slides with different proportions of rock, soil and vegetation (Fig. 2), rock falls and debris flows were triggered by the earthquake. A landslide susceptibility map was generated in order to provide scientifically sound tools to manage the crisis to the authorities (Naranjo et al., 2007a; Arenas et al., 2008). The scarps, main bodies and flow path of these landslides, were preliminary mapped and reported by the Sernageomin (Naranjo et al., 2007b²)

Landslides occurred on the steeper slopes mainly to the east of the zone of the epicentre, along the northern coast of the fjord. Most minor landslides were concentrated along the valley of Río Cuervo and on the western slope of Bahía Acantilada (Fig. 1). A minor debris flow destroyed Aquachile installations (Río Frío) and two young workers disappeared (Fig. 3). Rock falls and soil-vegetation slides on the eastern slope of Cerro Marchant, located $2 \mathrm{~km}$ to the northwest of Puerto Aisén, caused panic and the destruction of a house.

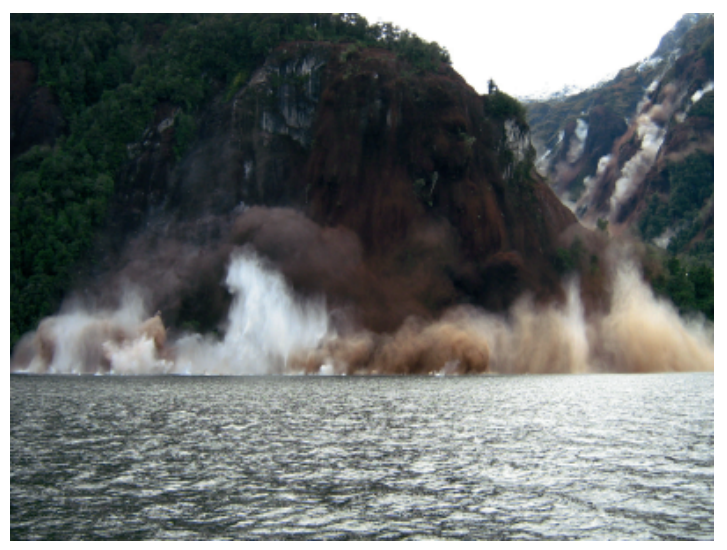

FIG. 2. Mainly soil and forest mass movement occurred in a 120 $\mathrm{m}$ high scarp on the northern shore of the fjord, $\sim 1 \mathrm{~km}$ to the east of Isla Mentirosa. View to the north. Courtesy of F. Olivera.
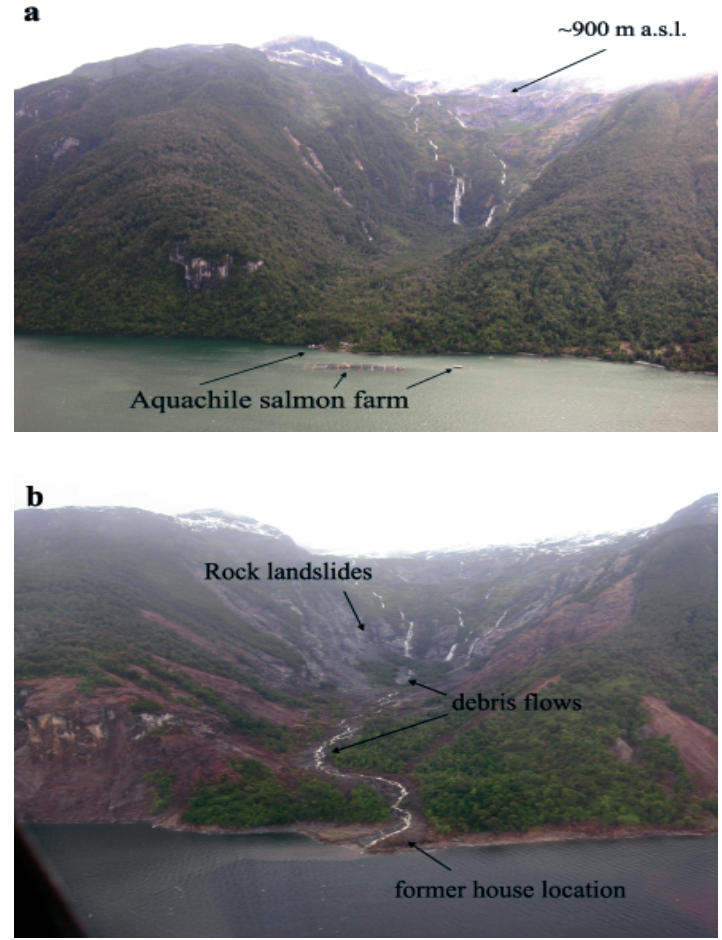

FIG. 3. a. Steep slopes of the Estero Frío Quebrada and the Aquachile salmon farm installations as before the April 212007 seismic event. Photograph by J.A. Naranjo; b. A number of scars and marks were left on the slopes after the earthquake. Local mass movements were transformed to a confined debris flow. After devastating Aquachile salmon farm installations, the debris flow thrusted into the fjord. Photograph by J.A. Naranjo.

The characteristic parameters of larger and voluminous landslides that triggered tsunamis when entering the fjord are shown in table 1. These data, together with those of other potential landslides in specific zones, allowed calibration and modelling of tsunami flooding in the Fiordo Aisén (SHOA, 20073; Clavero et al., 2008). Table 1 refers to rock slides north of Isla Mentirosa, a rock slide east of Aguas Calientes along the southern coast of the Fiordo Aisén and a debris flow at Quebrada Sin Nombre, close to Punta Cola (Figs. 1, 4, 5, 6), which was later interpreted as a rock avalanche by Sepúlveda and Serey (2009, this volume). Some recent interpretations of photographs indicate that the eastern section of the rock slide north of Isla

\footnotetext{
2 Naranjo, J.A.; Arenas, M.; Clavero, J.; Lara, L. 2007b. Estudio preliminar de peligros por remociones en masa por el sismo -Mw 6,2del 21 de abril de 2007, Región de Aisén. Servicio Nacional de Geología y Minería. Santiago (unpublished).

3 SHOA. 2007. Puerto Aisén-Puerto Chacabuco. Cartas de inundación por tsunami generado por remociones en masa. Servicio Hidrográfico y Oceanográfico de la Armada de Chile (unpublished).
} 
TABLA 1. LANDSLIDE-INDUCING TSUNAMIS.

\begin{tabular}{cccc}
\hline Parameter & $\begin{array}{c}\text { North Isla Mentirosa } \\
\text { (multiple slide) }\end{array}$ & $\begin{array}{c}\text { East Aguas Caliente } \\
\text { (single slide) }\end{array}$ & $\begin{array}{c}\text { Quebrada Sin Nombre } \\
\text { (debris flow) }\end{array}$ \\
\hline Mass volume entered into water (millions of $\left.\mathrm{m}^{3}\right)$ & $7 \pm 1$ & $1,7 \pm 0,3$ & $12 \pm 2$ \\
Mass that entered into water $(\mathrm{m})$ & $1.000 \pm 100$ & $34 \pm 5$ & $250 \pm 25$ \\
Maximum speed $(\mathrm{m} / \mathrm{s})$ & $100 \pm 10$ & $17 \pm 3$ & $30 \pm 5$ \\
Estimated speed when entering into water $(\mathrm{m} / \mathrm{s})$ & $50 \pm 5$ & & $15 \pm 3$ \\
\hline
\end{tabular}

(From Clavero et al., 2008)
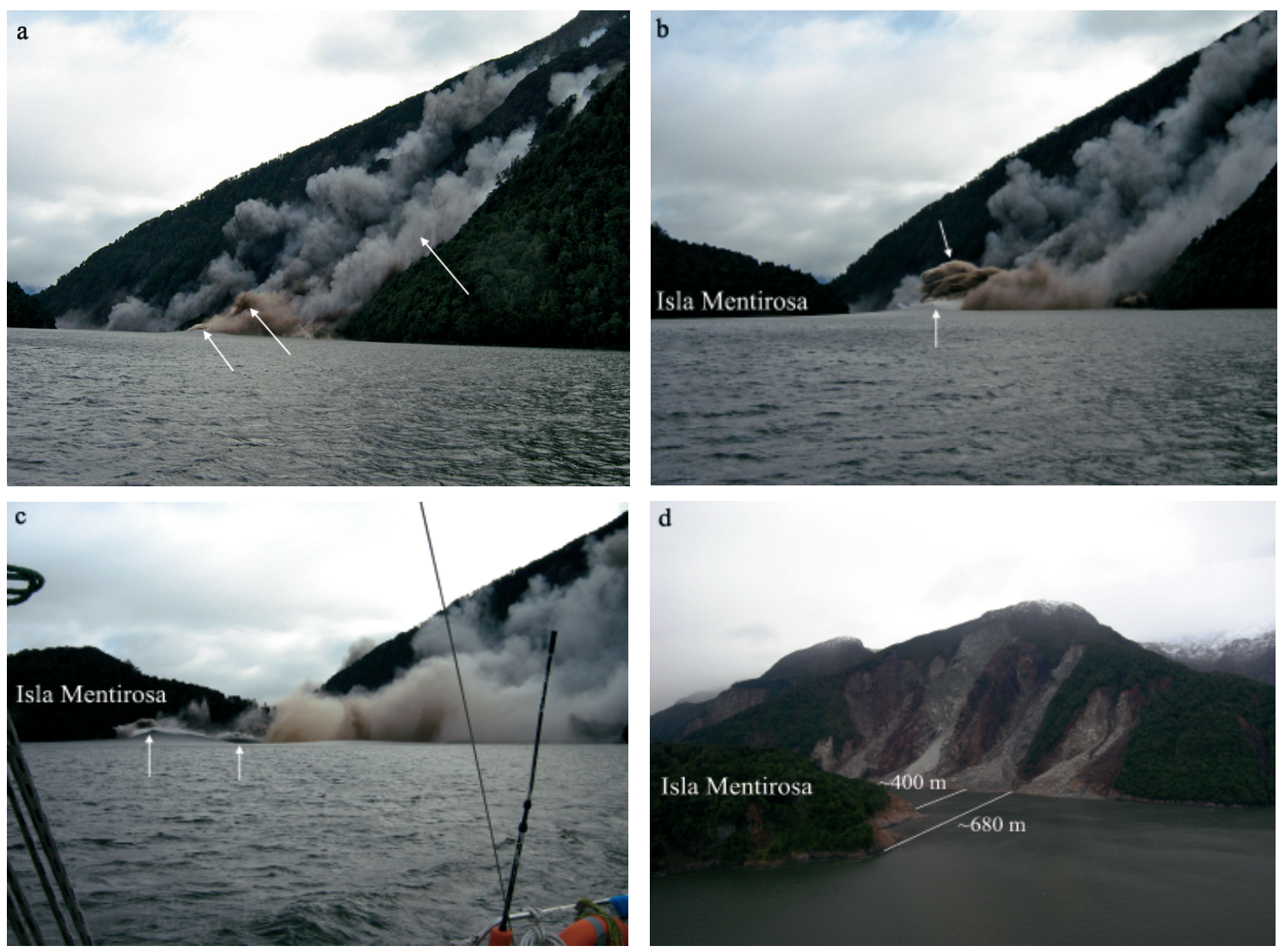

FIG. 4. Photograph succession of the multiple mainly rock landslide to the north of Isla Mentirosa. a. View to the northwest, time T1 (=10 seconds after the photograph in Fig. 2). A white to greyish cloud rising from the scar surface is indicated; in the foreground the initiation of the brown cloud alter the soil collapse is also noted, as well as the early water tumescence produced by the easternmost rock-mass intrusion. View to the northwest. Courtesy of F. Olivera; b. T1+6 sec; the wave amplitude increased moving to the left (south) produced by the easternmost rock-mass intrusion. In the background, the splash of brown soil of the second landslide is shown. View to the northwest. Courtesy of F. Olivera; c. T1+22 sec; left foreground, the first wave already impacted Isla Mentirosa's eastern coast after $\sim 500 \mathrm{~m}$ displacement from T1. At the centre, in the background, the second wave impacting (beating?) the island is shown. View to the northwest. Courtesy of F. Olivera; d. Oblique airborne view to the NNW. The compound landslide scar and the effects of the wave impacts are exhibited. Photograph by J.A. Naranjo. 

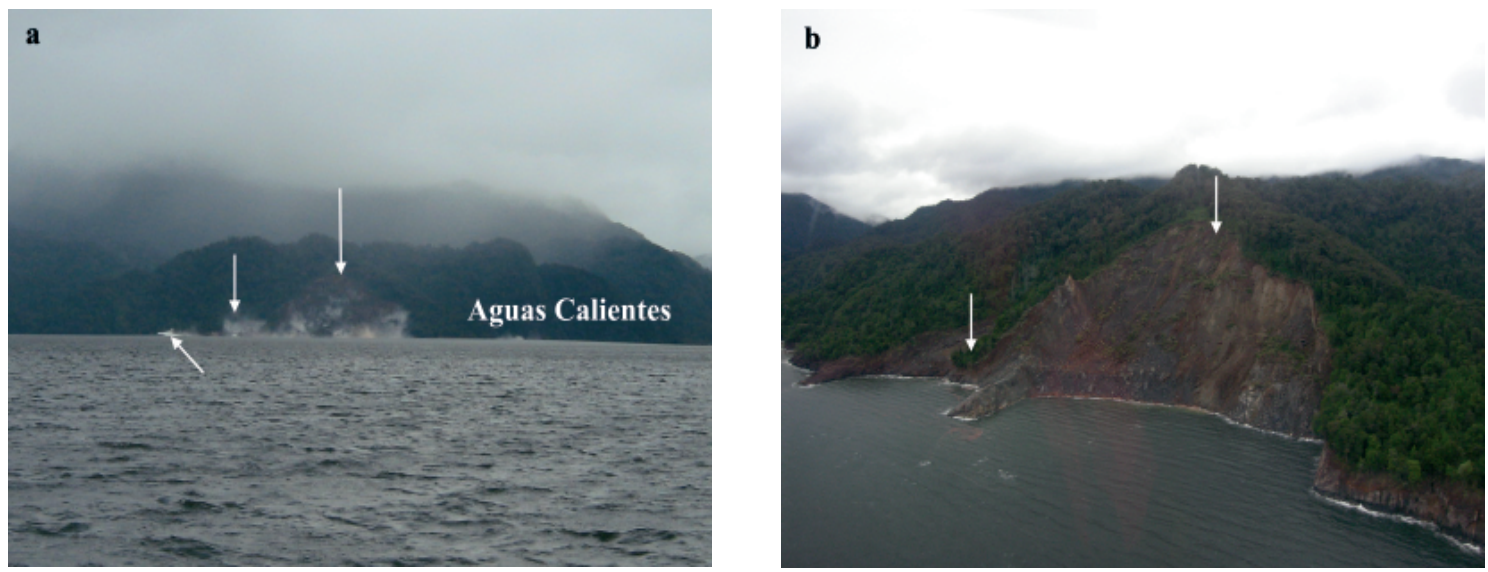

FIG. 5. Rock landslide to the east of Aguas Calientes in the Fiordo Aisén southern shore. a. Photograph taken 4 sec after image in figure $4 \mathrm{~b}$ shows the rock landslide (centre), while immediately to the east (left) a soil and forest earthflow occurs. The forming tsunami is also noticed. View to the southwest. Courtesy of F. Olivera; b. Oblique airborne view to the south note the scars left by the landslides. Photograph by M. Arenas.
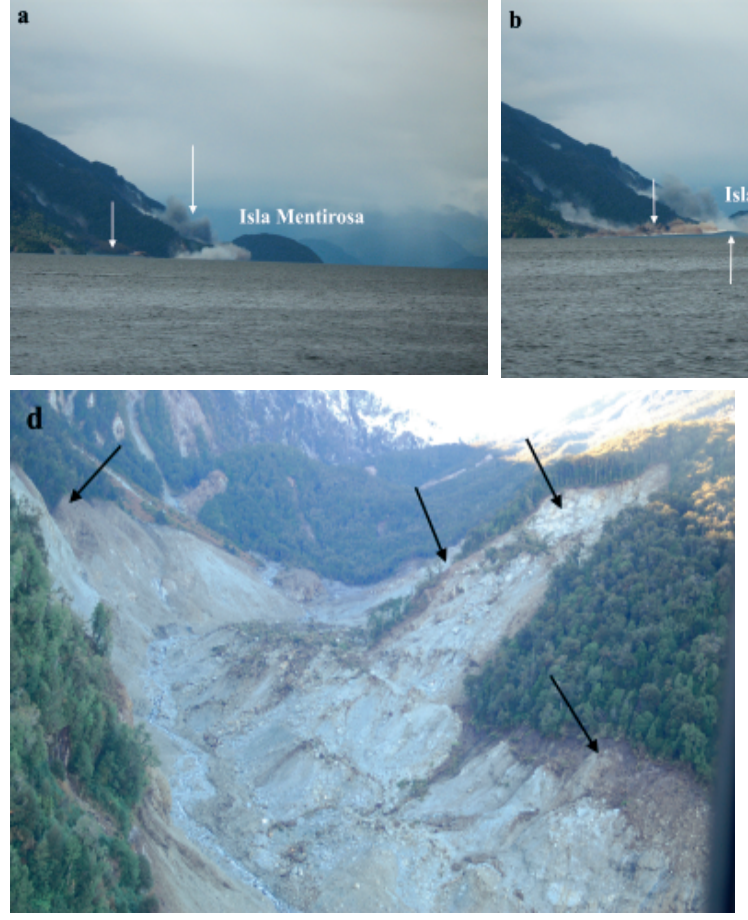
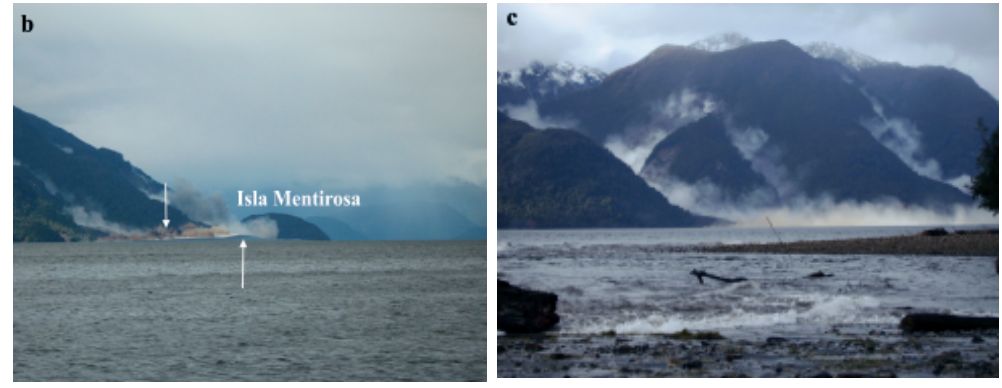

e

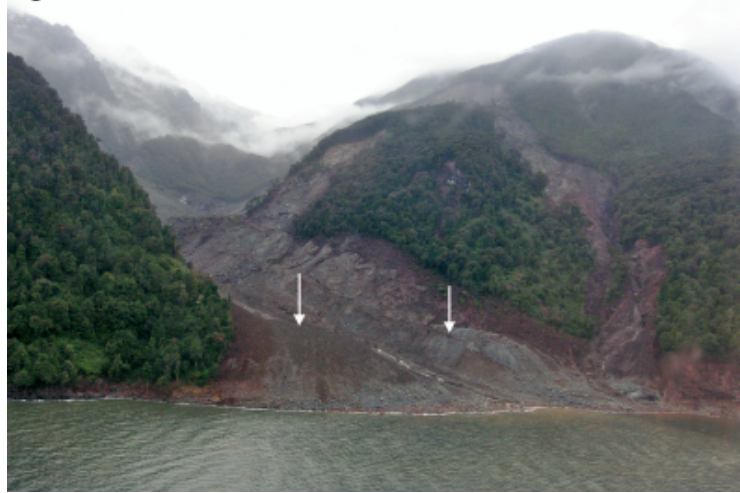

FIG. 6. Complex mass movement at Quebrada Sin Nombre, to the west of Isla Mentirosa, northern coast of Fiordo Aisén. a. The debris flow just sunk into the fjord; brown cloud of dust developed. The northern Isla Mentirosa landslide is in the background. View to the east from the fjord. Courtesy of Don Mario, a diver from Puerto Aisén; b. Photograph taken $18 \mathrm{sec}$ after figure 6a, shows the probably low angle displacement of the cohesive debris flow mass thrusting into the fjord which generates a sizeable tsunami. View to the east from the fjord. Courtesy of Don Mario, a diver from Puerto Aisén; $\mathbf{c}$. Whitish clouds slowly rising from the mass movements emplaced at Quebrada Sin Nombre, to the west of Isla Mentirosa. Picture taken to the east from Playa Blanca, approximately 50 sec before the first tsunami arrived at this locality. Courtesy of J. Contreras; d. Collapse scars at the headwaters of the Quebrada Sin Nombre, $4 \mathrm{~km}$ to the northwest of Isla Mentirosa. Also shown are the super elevation marks (left) and lateral marks (right) left behind by the thick debris flow probably transformed from an initial debris avalanche (Scott et al., 2001). Oblique aerial view to the north. Photograph by J.A. Naranjo; e. Earthflow (soil and forest) scars on the eastern slope at the mouth of the Quebrada Sin Nombre. Levée and central channel of the deposit are indicated. View to the northeast from the fjord. Courtesy of M. Arenas. 
Mentirosa collapsed at least 6 seconds before the central section of the slide (Fig. 4).

\section{Tsunamis}

A detailed study of photographs taken from eyewitnesses allowed to determine which landslides and/or debris flows generated megatsunamis* and to estimate a more precise chronology of the events that followed the earthquake at the Fiordo Aisén. The sudden steep flank failures incorporated important rock masses (mainly rocks and debris) into the fjord's water. This incorporation of rock and debris was the direct cause of tsunami generation just north of Isla Mentirosa and at the mouth of the Quebrada Sin Nombre in the northern part of the fjord; as well as to the east of Aguas Calientes in the southern part of the fjord (Figs. 4, 5 and 6). The failures occurred almost simultaneously and within less than a minute after the main earthquake.

The displaced water formed a wavy surface on their surface, estimated in up to 5 to $10 \mathrm{~m}$ high in the case of the Aguas Calientes area (M. Novy, oral communication, 2007). In few seconds, a series of tsunamis that reached estimated radial propagation speeds between 150 and $200 \mathrm{~km} / \mathrm{h}$ were formed from these wavy surfaces.

The direct impact of the displaced water onto the northern flank of Isla Mentirosa destabilized the soil and vegetation cover, leaving impact marks up to several tens of meters high (Fig. 4). However, in shallower areas, the inertia of the displaced water, generated run-outs into the main land of several hundred meters ( $<300 \mathrm{~m}$ at Río Pescado), causing destruction of coastal areas with gentle slopes (Naranjo et al., 2007a, b). The main areas affected by the tsunami were Punta Tortuga (one missing person), the mouth of Río Pescado, and Playa Blanca (Fig. 7; three dead and three missing people), the mouth of Río Cuervo, Punta Camello (Caleta Dagny y Ensenada La Perra, one missing person), Isla Mentirosa, the mouths of Frío and Fernández rivers, Punta Yelcho, Caleta Bluff and Bahía Acantilada.

\section{Discussion and conclusions}

The Aisén seismic swarm started on January 22 and had its peak on April 21, 2007 with a Mw 6.2

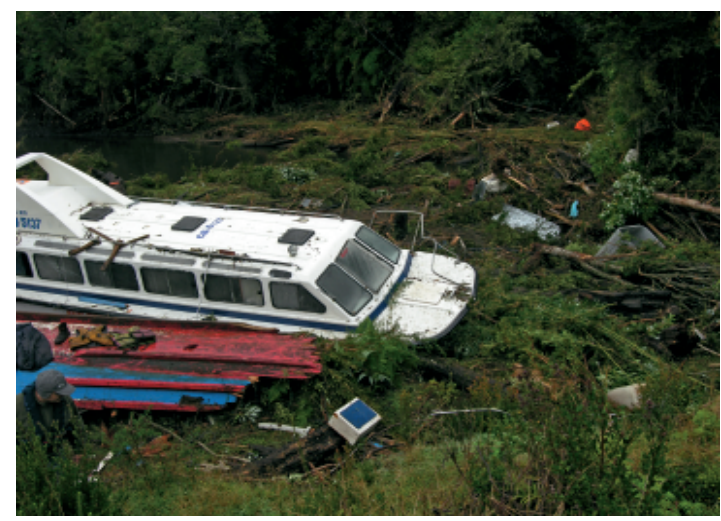

FIG. 7. To the west of Playa Blanca, the tsunami swept boats along Río Pescado for more than $300 \mathrm{~m}$ upstream from the fjord shore. In the background, mark left by the wave stay at $8 \mathrm{~m}$ a.s.1. Photograph by J.A. Naranjo.

earthquake ( $<9 \mathrm{~km}$ deep), which generated a series of mass movements (landslides and debris flows) along the steep flanks of the Fiordo Aisén that formed destructive tsunamis (se also Sepúlveda and Serey, 2009, this volume). During the initial three months of the seismic swarm (January-March) more than 7,000 earthquakes were registered. The long-lasting seismic activity caused fear and panic, as well as several other psychological effects in the nearby population, mainly inhabitants of Puerto Chacabuco and Puerto Aisén, and people working on the salmon farms located in the Fiordo Aisén. The complexity of the process, which was felt as a novelty (the last time a similar process occurred in the area was in 1927, when a small population was settled in the region), together with the structural features of the LOFZ that controls the emplacement of the ubiquitous volcanic structures, generated important interpretative controversies within the scientific community about the possible origin of the seismic swarm (tectonic and/or magmatic). This controversy affected the political authorities as well as the community, generating more alarm and credibility problems of the scientific team leading the monitoring of the phenomenon.

The sudden introduction of voluminous rock and debris masses $\left(1.7 \times 10^{6} \mathrm{~m}^{3}\right.$ at $17 \mathrm{~m} / \mathrm{s} ; 7 \times 10^{6} \mathrm{~m}^{3}$ at $50 \mathrm{~m} / \mathrm{s}$ and $12 \times 10^{6} \mathrm{~m}^{3}$ at $15 \mathrm{~m} / \mathrm{s}$ ) into the Fiordo Aisén waters generated tsunamis that propagated

\footnotetext{
" The term megatsunami indicates a tsunami that has an initial wave amplitude or height of several tens or hundreds of metres, much larger than a normal tsunami. Most megatsunamis have originated from large scale impact events such as landslides, devastating volcanic eruptions, or meteor impacts; e.g., Miller (1960), Mader (1999). In turn, normal tsunamis originate from tectonic activity and the raising or lowering of the sea floor.
} 
radially at an estimated speed of 150 to $200 \mathrm{~km} / \mathrm{h}$. Although these waves caused most of the victims, two people dissapeared as a direct consequence of debris flow emplacement in the devastated area of the Río Frío. Patagonia is a scarcely populated region of the world and the Fiordo Aisén, in particular, is an area with a city on its eastern margin (Puerto Aisén) and with sporadic installations for salmon industry along its margins. The tsunamis of April 21, also destroyed salmon farms near the shore, especially at the mouth of rivers and streams that provide water for the industrial process.

The witnesses reports about the phenomena that occurred in 1927 and on April 21, 2007, are coincident in terms of their effects. It is particularly interesting that an erroneous association is made, in both cases, with volcanic processes. This interpretation made by local people, is probably due to the fact that the falling rock masses generated, by friction, dust and water vapour clouds (which were observed on April 21, 2007, Figs. 4a-c and 6c). These clouds are transported vertically, because of their low density, for several tens up to hundreds of meters-high, and their smell is commonly associated by people with sulphur, which is itself commonly associated with volcanic activity. Usually, during the transport processes of landslides and/or debris flows there is an important energy loss (friction and heat), which can cause a velocity decrease of up to $50 \%$ of the flows (McSaveney and Davies, 2006). The abundance of volcanic-derived material, such as pumice and scoria debris in the area, from the numerous pyroclastic cones and stratovolcanoes (D'Orazio et al., 2003) is another factor that helps misinterpreting this kind of process. However, the occurrence of volcanic eruptions in the fjord area in recent times cannot be ruled out. For example, in Ensenada Pérez (about $10 \mathrm{~km}$ northwest of the locality in Fig. 1, where most witnesses say an eruption occurred early in the $20^{\text {th }}$ century), there is field evidence of very younglooking volcanic lavas and pyroclastic cones (on the southwestern flank of Macá volcano).

The published inventory map of the mass movements generated on April 21, 2007 and the landslide/ debris flow susceptibility map that followed (Naranjo et al., 2007b) could form the basis for the generation and application of new emergency plans as well as new land-use plans, before more detailed studies are carried out in the area.

As a concluding remark, the initial lack of coordination of the scientific team would have been avoided if the IAVCEI crisis protocol (IAVCEI, Subcommitee for Crisis Protocols, 1999) would have been enforced from the beginning.

\section{Acknowledgments}

The authors thank Mr. C. Manríquez, Regional Mining Ministry Secretary for his collaboration during field work; Mr. J. Burgos, Regional National Property Ministry Secretary for digital topographic information; Mr. V. Vallejos and J. E. Barrientos for the field work coordination. We are indebted to all the people of the region and especially the Regional Government for all their support. We also appreciate the photographic material provided by Mr. F. Olivera and Mr. J. Contreras. Finally, we want to thank the referees Mr. F. Hervé, S. Sepúlveda, D. Morata and M. Suárez for their comments that helped improving the original manuscript.

\section{References}

Arenas, M.; Naranjo, J.; Clavero, J.; Lara, L. 2008. Earth quake-induced landslides: susceptibility mapping for crisis management. In Congreso Geológico Argentino, No. 17, Actas 1: 255. Salvador de Jujuy.

Barrientos, S.; Bataille, K.; Aranda, C.; Legrand, D.; Báez, J.C.; Agurto, H.; Pavez, A.; Genrich, J.; Vigny, C.; Bondoux, F. 2007. Complex sequence of earthquakes in Fiorland, Southern Chile. In Geosur 2007: 21.

Cembrano, J.; Hervé, F.; Lavenu, A. 1996. The LiquiñeOfqui fault zone: A long lived intraarc fault system in southern Chile. Tectonophysics 259: 55-66.

Cembrano, J.; González, G.; Lara, L.; Medina, E.; Aron, F.; Basso M.; Ortega, V.; Pérez, P.; Sielfeld, G. 2008. The interplay between crustal tectonics and volcanism in the Central and Southern Volcanic zones of the Chilean Andes. In International Symposium on Andean Geodynamics, No. 7. Nice.

Clavero, J.; Arenas, M.; Naranjo, J.; Lara, L. 2008. Parameterization of earthquake-induced landslides for tsunami modelling in southern Chile. In Congreso Geológico Argentino, No. 17, Actas 1: 267. Salvador de Jujuy.

D’Orazio, M.; Innocenti, F.; Manetti, P., Tamponi, M.; Tonarini, S.; González-Ferrán, O.; Lahsen, A.; Omarini, R. 2003. The Quaternary calc-alkaline volcanism of the Patagonian Andes close to the Chile triple junction: geochemistry and petrogenesis of volcanic rocks from the Cay and Maca volcanoes $\left(\sim 45^{\circ} \mathrm{S}\right.$, Chile). Journal of South American Earth Sciences 16: 219-242.

Gutiérrez, F.; Gioncada, A.; González-Ferrán, O.; Lahsen A.; Mazzuoli, R. 2005. The Hudson volcano and surrounding monogenetic centres (Chilean Patagonia): an example of volcanism associated with ridge-trench collision environment. Journal of Volcanology and Geothermal Research 145: 207-233. 
IAVCEI, Subcommitee for Crisis Protocols. 1999. Bulletin of Volcanology 60: 323-334.

Hervé, M. 1976. Estudio geológico de la falla LiquiñeReloncaví en el área de Liquiñe: Antecedentes de un movimiento transcurrente (Provincia de Valdivia). In Congreso Geológico Chileno, No. 1, Actas 1: B39B56. Santiago.

Hervé, M. 1984. La zona de falla Liquiñe-Ofqui en Liquiñe. Comunicaciones 34: 101-105.

Hervé, F.; Araya, E.; Fuenzalida, J.L.; Solano, A. 1979. Edades radiométricas y tectónica neógena en el sector costero de Chiloé continental, X Región. In Congreso Geológico Chileno, No. 2, Actas 1: F1-F18. Arica.

Lange, D.; Cembrano, J.; Rietbrock, A.; Haberland, C.; Dahm, T.; Bataille, K. 2008. First seismic record for intra-arc strike-slip tectonics along the Liquiñe-Ofqui fault zone at the obliquely convergent plate margin of the southern Andes. Tectonophysics 455:14-24.

Mader, C.L. 1999. Modeling the 1958 Lituya Bay MegaTsunami. Science of Tsunami Hazards 17, 57-67.

McSaveney, M.J.; Davies, T.R.H. 2006. Rapid rock mass flow with dynamic fragmentation: inferences from morphology and internal structure of rockslides and rock avalanches. In Landslides from Massive rock Slope Failure. (Evans, S.G.; Scarascia Mugnozza, G.; Strom, A. and Hermanns, R.L.; editors). NATO Science Series, Springer: 285-304. The Netherlands.

Miller, D. 1960. Giant Waves in Lituya Bay Alaska. Geological Survey Professional Paper 354-C: 51-86.

Naranjo, J.A. 1991. Nueva erupción del volcán Hudson. Revista Geológica de Chile 18 (2): 183-184.
Naranjo, J.A.; Clavero, J.; Arenas, M.; Lara, L.; Moreno, M. 2007a. Efectos de la crisis sísmica de Aisén 2007.In Congreso Nacional, No. 28 y Congreso Internacional de Geografía, No. 13. Universidad de Chile, Facultad de Arquitectura, Urbanismo y Geografía, Resúmenes: 116 p. Santiago.

Naranjo, J.A.; Moreno, H.; Banks, N. 1993. La erupción del volcán Hudson en 1991 (46º S), Región XI, Aisén. Boletín 44, Servicio Nacional de Geología y Minería: $50 \mathrm{p}$.

Naranjo, J.A.; Stern, C.R. 2004. Holocene tephrochronology of the southernmost part $\left(42^{\circ} 30^{\prime}-45^{\circ} \mathrm{S}\right)$ of the Andean Southern Volcanic Zone. Revista Geológica de Chile 31 (2): 225-240.

Orihashi, Y.; Naranjo, J.A.; Motoki,A.; Sumino, H; Hirata, D.; Anma, R.; Nagao, K. 2004. Quaternary olcanic activity of Hudson and Lautaro volcanoes, Chilean Patagonia: new constraints from K-Ar ages. Revista Geológica de Chile 31 (2): 207-224.

Scott, K.; Macías, J.L.; Naranjo, J.A.; Rodríguez, S.; McGeehin, J.P. 2001. Catastrophic debris flows transformed from landslides in volcanic terrains: mobility, hazard assessment, and mitigation strategies. U.S. Geological Survey Professional Paper 1630: $59 \mathrm{p}$.

Sepúlveda, S.; Serey, A. 2009. Tsunamigenic, earthquaketriggered rock slope failures during the 21 st of April 2007 Aysén earthquake, southern Chile $\left(45.5^{\circ} \mathrm{S}\right)$. Andean Geology 36 (1): 131-136.

SERNAGEOMIN. 2002. Mapa Geológico de Chile. Servicio Nacional de Geología y Minería, Carta Geológica de Chile, Serie Geología Básica 75, escala $1: 1.000 .000$. 